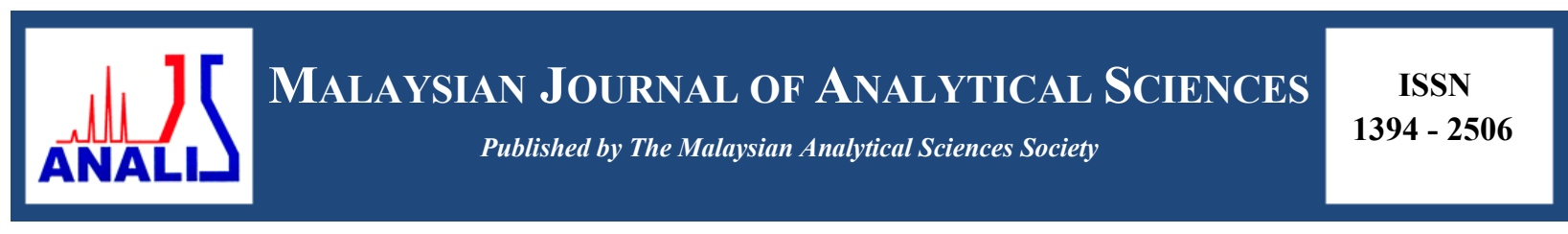

\title{
OPTIMIZATION OF SELECTED CHARCOAL POWDER COMPOSITE ELECTRODE FOR ELECTROCHEMICAL TREATMENT OF LANDFILL LEACHATE
}

\author{
(Pengoptimuman Komposit Elektrod daripada Serbuk Arang Terpilih untuk Rawatan \\ Elektrokimia Bahan Larut Lesap Tapak Pelupusan) \\ Majd Ahmed Jumaah ${ }^{1}$, Mohamed Rozali Othman ${ }^{1,2}$, Jumat Salimon ${ }^{1}$, Baydaa Khalaf ${ }^{1}$, \\ Wan Mohd Afiq Wan Mohd Khalik ${ }^{2,3}$ \\ ${ }^{1}$ School of Chemical Sciences and Food Technology, Faculty of Science and Technology \\ ${ }^{2}$ Centre for Water Research and Analysis, Faculty of Science and Technology \\ Universiti Kebangsaan Malaysia, 43600 UKM Bangi, Selangor, Malaysia \\ ${ }^{3}$ School of Marine and Environmental Sciences, \\ Universiti Malaysia Terengganu, 21030 Kuala Nerus, Terengganu, Malaysia \\ *Corresponding author: majd.ahmed88@yahoo.com
}

Received: 19 October 2017; Accepted: 29 January 2018

\begin{abstract}
Charcoal powders obtained from commercially available charcoal and the open burning of palm oil, rubber, coconut, and mangrove trees were used to fabricate composite electrodes in this study. A weight portion of charcoal powder, graphite, cobalt, and polyvinyl chloride $\left(\mathrm{C}-\mathrm{C}^{\mathrm{G}}\right.$-Co-PVC) were mixed in tetrahydrofuran (THF). The fabricated composite electrodes were then used as working electrodes for the electrochemical treatment of landfill leachate samples. A variable pressure scanning electron microscope (VPSEM) was used to examine the appearance of the charcoal powder. The results showed that rubber tree charcoal powder is the best charcoal powder for fabricating the composite electrodes, as it has various pore sizes and more surface area available for adsorption and reaction. Field emission scanning electron microscopy (FESEM) was performed before and after electrolysis of the landfill leachate. The results revealed that the presence of voids on the electrode surface before and after electrolysis improved the electrochemical oxidation of the landfill leachate, and yielded removal percentages in colour, COD, $\mathrm{NH}_{3}-\mathrm{N}$, and total $\mathrm{P}$ of not less than $80 \%, 91 \%, 73 \%$, and $84 \%$, respectively.
\end{abstract}

Keywords: landfill leachate, charcoal powder, composite electrode, electrochemical method

\begin{abstract}
Abstrak
Serbuk arang yang diperoleh dari arang komersil dan pembakaran terbuka batang-batang pokok kelapa sawit, pokok getah, pokok kelapa, dan pokok bakau telah digunakan untuk membina elektrod komposit berasaskan arang hasil gabungan serbuk arang, grafit, kobalt dan polivinil klorida $\left(\mathrm{C}-\mathrm{C}^{\mathrm{G}}-\mathrm{Co}-\mathrm{PVC}\right)$ yang telah dicampurkan mengikut komposisi berat tertentu dalam pelarut tetrahidrofuran (THF). Elektrod komposit yang telah dibina kemudiannya digunakan sebagai elektrod kerja untuk merawat sampel air bahan larut lesap melalui kaedah elektrokimia. Mikroskop elektron imbasan tekanan boleh ubah (VPSEM) telah digunakan untuk mengkaji sifat fizikal serbuk arang. Keputusan menunjukkan bahawa serbuk arang pokok getah merupakan serbuk arang terbaik untuk membina elektrod komposit dalam kajian ini kerana ia mempunyai banyak liang dan luas permukaan yang lebih tinggi untuk penjerapan dan tindak balas berlaku. Mikroskop imbasan elektron medan pancaran (FESEM) telah digunakan untuk memerhati permukaan elektrod yang telah disediakan sebelum dan selepas elektrolisis bahan larut lesap. Keputusan menunjukkan bahawa terdapat kehadiran lohong pada permukaan elektrod sebelum dan selepas elektrolisis. Hal ini
\end{abstract}




\section{Majd Ahmed Jumaah et al: OPTIMIZATION OF SELECTED CHARCOAL POWDER COMPOSITE ELECTRODE FOR ELECTROCHEMICAL TREATMENT OF LANDFILL LEACHATE}

membantu memperbaiki proses pengoksidaan elektrokimia bahan larut lesap yang telah menyebabkan peratus pengurangan warna, $\mathrm{COD}, \mathrm{NH}_{3}-\mathrm{N}$, dan total $\mathrm{P}$ masing-masingnya tidak kurang daripada $80 \%, 91 \%, 73 \%$, dan $84 \%$.

Kata kunci: bahan larut lesap tapak pelupusan, serbuk arang, elektrod komposit, kaedah elektrokimia

\section{Introduction}

Municipal councils and cities around the world commonly use sanitary landfills to manage solid waste [1]. The increased growth in population, urbanisation, and industrialisation has resulted in a high amount of solid wastes being generated. The generation of municipal solid waste is increasing day-by-day due to the rapid development of urban areas and rural-urban migration. After landfilling, solid waste undergoes physico-chemical and biological changes. Consequently, the degradation of the organic fraction of the wastes in combination with percolating rainwater leads to the production of a dark-coloured, highly polluted liquid called "leachate" [2]. Landfill leachate contains high concentrations of pollutants such as ammonia, phosphorus, and total dissolved solid as well as high chemical oxygen demand (COD). Leachates are fast becoming an issue in wastewater sources since it can cause serious pollution to the ecosystem [3]. Humid substances represent more than $60 \%$ of the total organic carbon found in anaerobic landfill leachates.

In an effort to control the pollution caused by landfill leachate, various treatment processes have been studied, including biological treatment [4], photocatalysis [5], adsorption [6], chemical precipitation [7], Fenton's oxidative treatment [8], coagulation/flocculation [9], advanced oxidation processes, and membrane processes [10]. However these methods still have disadvantages such as decreased treatment efficiencies and increased cost. Up until now, the electrochemical oxidation process has been proven to be the more promising wastewater treatment method mainly due to its high effectiveness, ease of operation, and economy. This method is particularly suited for landfill leachate treatment because the rich chloride ions and good conductivity of the leachates enhance the benefits of the electrochemical method. The electrochemical oxidation technique is an effective method not only for colour removal but also for COD removal. The pollutants are destroyed through a direct or indirect oxidation process [11].

The choice of anode material is critical and considered a major experimental concern because the anode serves as the site for oxidation reaction and electrochemical catalysis. Therefore, the selection of materials for fabricating a working electrode (anode) is crucial, so as to produce high oxidation efficiency and high electrochemical catalysis. Meanwhile, the effect of cathode materials has not been extensively investigated, although it may have a considerable influence on the electro-oxidation of organic compounds [12]. However, the electrode material must have the following properties: high physical and chemical stability, high electrical conductivity, rapid electron transfer kinetics in a wide range of redirections, ease of setup as well as inexpensive and durable [13]. Different types of anode materials such as $\mathrm{Pt}, \mathrm{PbO}_{2}, \mathrm{Al}$, and graphite have been investigated for electrochemical treatment $[14,15]$.

In the present study, a novel charcoal-based metallic composite electrode is proposed as an electrode material to treat landfill leachate. Out of the several types of carbon, charcoal was selected because other carbon types such as diamond and graphite are expensive. The study also investigates different types of charcoal prepared from palm oil, rubber, coconut, and mangrove trees as well as available commercial charcoal to determine the best type for treating landfill leachate. The efficiency of charcoal carbon in wastewater treatment is due to its low cost compared to other materials as well as its ability to absorb organic compounds and other pollutants from the leachate [16].

\section{Sampling and analysis}

\section{Materials and Methods}

Leachate samples were collected from Jeram Sanitary Landfill, which is located in an oil palm plantation near Mukim Jeram, Kuala Selangor, Malaysia. The samples were collected in $1 \mathrm{~L}$ amber glass bottles with Teflon-lined caps to ensure sample integrity, using a stainless steel bucket previously rinsed with distilled water and methanol. The bottle headspace was kept to a minimum by filling the bottles until the top. The bottles were rinsed in the field with the sample and filled to the top on the second sampling. Disposable gloves were used to prevent any contamination. The samples were transported to the laboratory in an ice-cooled container and stored at $4{ }^{\circ} \mathrm{C}$ in order to retain the leachate characteristics. Finally, all samples were characterised based on selected parameters such as 
$\mathrm{pH}$, colour, and COD. The tests were conducted according to the Standard Methods for the Examination of Water and Wastewater [17]. COD and colour were measured using a HACH DR2400 spectrophotometer. The pH was measured using a pH meter (EUTECH pH 2700).

\section{Preparation of electrodes}

Composite electrodes at a composition of $\mathrm{C}: \mathrm{C}^{\mathrm{G}}: \mathrm{Co}: \mathrm{PVC}$ were fabricated accordingly as per a previous study, by mixing together a weighed portion of charcoal powder $0.5 \mathrm{~mm}$ graphite and Co with PVC in $4 \mathrm{ml}$ THF solvent and swirled flatly into a homogeneous composition, followed by drying in an oven at $100{ }^{\circ} \mathrm{C}$ for 3 hours $[3,18]$.The mixture was then placed in a $1-\mathrm{cm}$ diameter stainless steel mould and pressed at $10 \mathrm{ton} / \mathrm{cm}^{2}$. A typical pellet contains approximately $60 \%(\mathrm{w} / \mathrm{w})$ charcoal powder, $15 \%(\mathrm{w} / \mathrm{w})$ graphite, $10 \%(\mathrm{w} / \mathrm{w})$ Co, and $15 \%(\mathrm{w} / \mathrm{w})$ PVC powder. The total weight of the pellet obtained was approximately $0.5 \mathrm{~g}$. The pellets were connected to a silver wire with silver conducting paint prior to being covered with epoxy gum. A weight ratio of $C: C^{G}: C o: P V C$ was used for the prepared electrodes, as summarised in Table 1.

Table 1. Weight ratio and composition of charcoals, graphite, metal, and PVC powders for the prepared electrodes

\begin{tabular}{lccccc}
\hline Electrode & $\begin{array}{c}\text { Ratio } \\
\text { C:C }\end{array}$ & $\begin{array}{c}\mathbf{C} \\
\text { Co:PVC }\end{array}$ & $\begin{array}{c}\mathbf{C}^{\mathbf{G}} \\
(\mathbf{g})\end{array}$ & $\begin{array}{c}\text { Co } \\
(\mathbf{g})\end{array}$ & $\begin{array}{c}\text { PVC } \\
(\mathbf{g})\end{array}$ \\
\hline $\mathrm{C}^{\text {coconut }} \mathrm{C}_{15}^{\mathrm{G}} \mathrm{Co}_{10} \mathrm{PVC}_{15}$ & $60: 15: 10: 15$ & 0.3 & 0.075 & 0.05 & 0.075 \\
$\mathrm{C}^{\text {rubber tree }}{ }_{60} \mathrm{C}_{15}^{\mathrm{G}} \mathrm{Co}_{10}-\mathrm{PVC}_{15}$ & $60: 15: 10: 15$ & 0.3 & 0.075 & 0.05 & 0.075 \\
$\mathrm{C}^{\text {mangrove }}{ }_{60} \mathrm{C}_{15}^{\mathrm{G}} \mathrm{Co}_{10}-\mathrm{PVC}_{15}$ & $60: 15: 10: 15$ & 0.3 & 0.075 & 0.05 & 0.075 \\
$\mathrm{C}^{\text {palm oil }}{ }_{60} \mathrm{C}_{15}^{\mathrm{G}}{ }_{15} \mathrm{Co}_{10}-\mathrm{PVC}_{15}$ & $60: 15: 10: 15$ & 0.3 & 0.075 & 0.05 & 0.075 \\
$\mathrm{C}^{\text {commercial }}{ }_{60} \mathrm{C}^{\mathrm{G}}{ }_{15} \mathrm{Co}_{10}-\mathrm{PVC}_{15}$ & $60: 15: 10: 15$ & 0.3 & 0.075 & 0.05 & 0.075 \\
\hline
\end{tabular}

Note* $\mathrm{C}=$ charcoal, $\mathrm{C}^{\mathrm{G}}=$ graphite

The surface morphology of the five charcoal powders used in this work was analysed using VP-SEM (LEO model $1450 \mathrm{VP})$, while the surface morphology of the composite electrodes before and after the electrochemical oxidation process was analysed using SEM (ZEISS, merlin compact model, Germany).

\section{The experimental setup}

The electrochemical cell setup consists of a DC power supply (CP x 200 DUAL, 35 V 10 A PSU) and a glass beaker $(250 \mathrm{ml})$ complete with a $\mathrm{C}_{60} \mathrm{C}^{\mathrm{G}}{ }_{15} \mathrm{Co}_{10} \mathrm{PVC}_{15}$ composite electrode as the anode and a stainless steel rod $(\mathrm{d}=$ $10 \mathrm{~mm}$ ) as the cathode (Figure 1). The electrodes were placed parallel to each other in the electrolytic reactor, with a distance of approximately $1 \mathrm{~cm}$ between the cathode and anode. Stirrers were used throughout to maintain homogeneity of the sample.

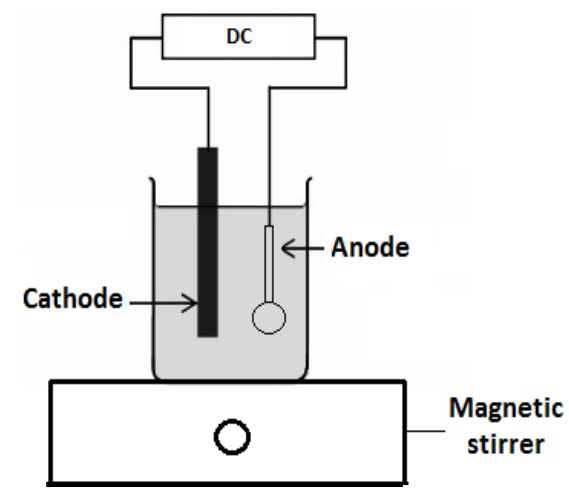

Figure 1. Schematic experimental setup 
Majd Ahmed Jumaah et al: OPTIMIZATION OF SELECTED CHARCOAL POWDER COMPOSITE

ELECTRODE FOR ELECTROCHEMICAL TREATMENT OF LANDFILL

LEACHATE

\section{Results and Discussion}

Study on the surface morphology of the five charcoal powders

VPSEM was used to examine the appearance of the charcoal powder obtained from five types of charcoal (Figures 2). Results of the VPSEM analysis show that charcoal powder particles are irregularly shaped, with different sizes [19]. Mangrove charcoal appears to have a smooth surface and a few holes. Meanwhile, some holes were also observed on the surface of commercially available charcoal. The palm oil charcoal has a structural shape and is non-coherent. This structure is not effective for absorbing pollutants. Coconut and rubber charcoal clearly have a wide variety of pores present along with a fibrous structure. Many holes are also found, which would contribute to more surface area available for adsorption and reaction [20]. The rubber tree charcoal powder was finally chosen as the best charcoal type for fabricating the electrode to treat the landfill leachate in this study, based on the two types of adsorptions that occur between organic compounds and the anode: (1) the physical adsorption involving Van der Waals forces; and (2) the chemical adsorption involving the formation of chemical bonds between the anode surface and organic compounds [21].
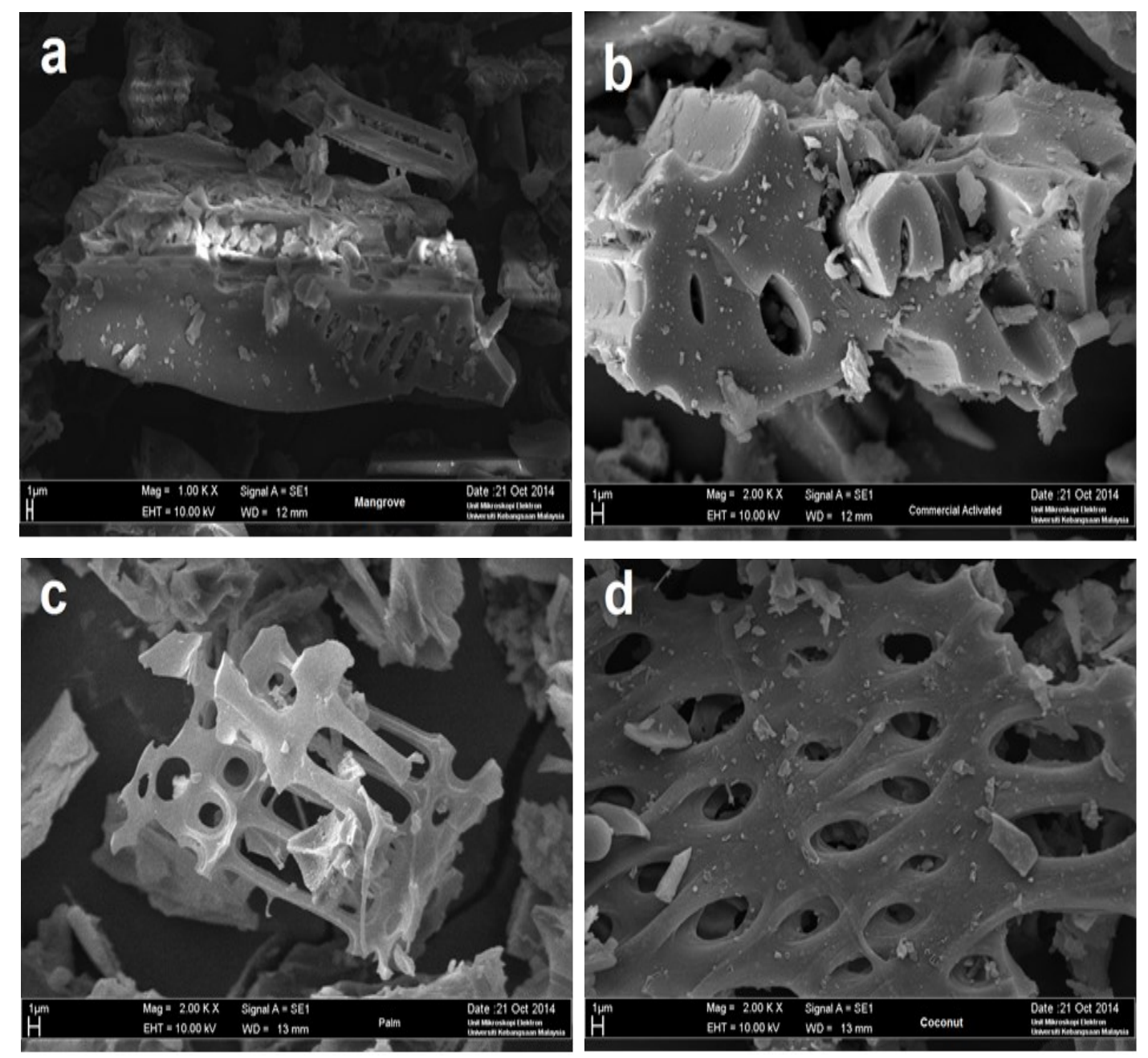


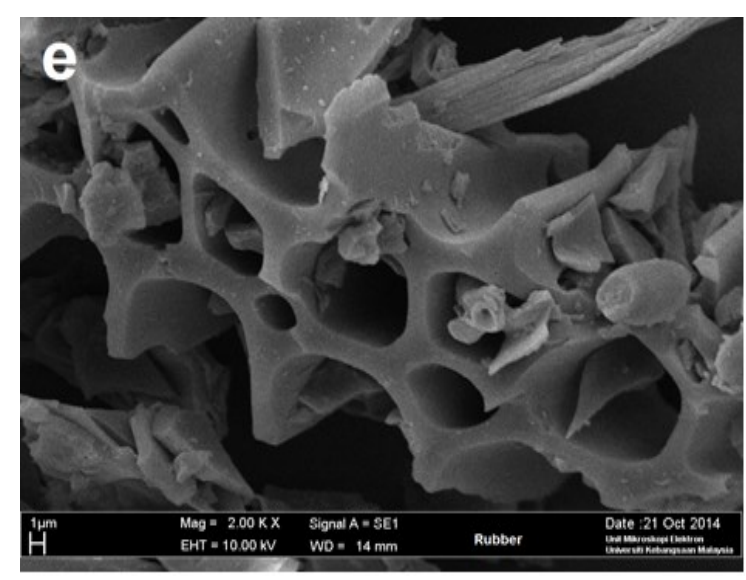

Figure 2. VPSEM of charcoal powder for: (a) Mangrove; (b) commercial charcoal; (c) palm oil; (d) coconut; and (e) rubber tree, using an accelerating voltage of $10 \mathrm{kV}$

\section{Colour removal}

Colour removal is of great interest in this study because colour is not just a parameter; it is also a good anthropogenic indicator $[22,23]$. The colour removal efficiency of different types of charcoal for fabricating the electrodes in this study is therefore investigated. The results obtained are summarised in Table 2.

Table 2. Electrochemical oxidation of landfill leachate using different charcoal composite electrodes

\begin{tabular}{lcll}
\hline Electrode composition & $\begin{array}{c}\text { Decolouring percentage } \\
(\mathbf{\%})\end{array}$ & \multicolumn{2}{c}{ Observation } \\
\cline { 3 - 4 } & 83 & Yellowish solution & Unchanged \\
\hline $\mathrm{C}^{\text {coconut }} \mathrm{C}_{15}^{\mathrm{G}} \mathrm{Co}_{10} \mathrm{PVC}_{15}$ & 80 & Yellowish solution & Unchanged \\
$\mathrm{C}^{\text {rubber tree }}{ }_{60} \mathrm{C}_{15}^{\mathrm{G}} \mathrm{Co}_{10}-\mathrm{PVC}_{15}$ & 57 & Yellowish solution & Slightly corroded \\
$\mathrm{C}^{\text {mangrove tree }}{ }_{60} \mathrm{C}_{15}^{\mathrm{G}}{ }_{15} \mathrm{Co}_{10}-\mathrm{PVC}_{15}$ & 65 & Yellowish solution & Unchanged \\
$\mathrm{C}^{\text {palm oil }}{ }_{60} \mathrm{C}_{15}^{\mathrm{G}}{ }_{15} \mathrm{Co}_{15} \mathrm{PVC}_{15}$ & 59 & Yellowish solution & Slightly corroded \\
$\mathrm{C}^{\text {commercially available }}{ }_{60} \mathrm{C}^{\mathrm{G}} 15$ & & &
\end{tabular}

Majd and Othman [14] used optimum operating conditions such as 120 min electrolysis time, an applied voltage of $10 \mathrm{~V}$, a sodium chloride concentration of $1.5 \%(\mathrm{w} / \mathrm{v})$ and $\mathrm{pH} 4$, with electrode compositions of $\mathrm{C}^{\text {coconut }}$ ${ }^{\text {tree }} \mathrm{C}^{\mathrm{G}}{ }_{15} \mathrm{Co}_{10} \mathrm{PVC}_{15}$ and $\mathrm{C}^{\text {rubber tree }}{ }_{60} \mathrm{C}^{\mathrm{G}}{ }_{15} \mathrm{Co}_{10} \mathrm{PVC}_{15}$, which yielded the best colour removal via the electrochemical treatment of landfill leachate, with a colour removal percentage of $83 \%$ and $80 \%$, respectively. However, the colour removal efficiencies for charcoal obtained from palm oil and mangrove trees and commercially available charcoal, were only $65 \%, 57 \%$, and $59 \%$, respectively. Therefore, it is clear that coconut and rubber electrode yield high colour removal and do not undergo any change in physical properties. The electrode used in any electrochemical process should be stable chemically and physically [24]. Therefore, based on these criteria, the best electrode must not only be able to remove colour, but also have the appropriate chemical and physically stability.

The results obtained for the electrodes fabricated from Mangrove tree charcoal and commercially available charcoal yielded the lowest colour removal percentages. Not only that, the electrodes also became slightly corroded. Although the charcoal obtained from palm oil has good chemical and physically stability, its colour removal efficiency is lower than the electrodes fabricated from coconut and rubber tree charcoal. These results correspond with the results of the SEM micrograph, which show the effectiveness of the electrodes fabricated from coconut and rubber trees in electrochemically treating landfill leachates. Although the electrode fabricated from coconut tree charcoal gave the highest colour removal efficiency, this charcoal type is difficult to obtain and is usually 
unavailable in the market. Therefore, the rubber charcoal composite electrode was selected as the best type of electrode in this case due to its effectiveness in removing colour and wide availability, especially in Malaysia [25].

\section{SEM of rubber tree charcoal-graphite- Co-PVC electrode}

The surface morphology of $\mathrm{C}^{\text {rubber tree }} \mathrm{C}^{\mathrm{G}} \mathrm{CoPVC}$ electrode was investigated using SEM. The SEM micrographs were obtained using an accelerating voltage of $15 \mathrm{kV}$ to evaluate the effectiveness of electrochemical oxidation before and after treatment (Figure 3).
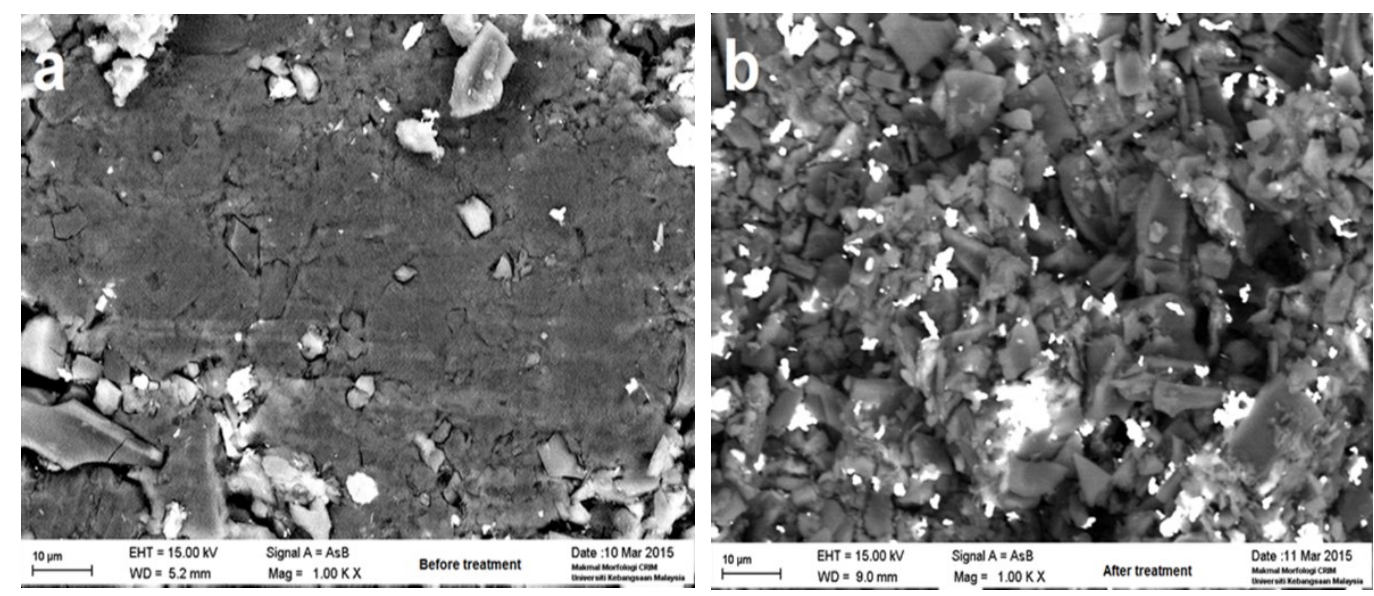

Figure 3. SEM micrograph of: (a) $\mathrm{C}^{\text {rubber tree }}{ }_{60} \mathrm{C}_{15}^{\mathrm{G}} \mathrm{Co}_{10} \mathrm{PVC}_{15}$ electrode before (a) and after (b) treatment of leachate

Figure 3(a) before electrolysis shows a smooth-surfaced electrode. There are no free holes on the surface of the $\mathrm{C}^{\text {rubber tree }}{ }_{60} \mathrm{C}_{15}^{\mathrm{G}} \mathrm{Co}_{10} \mathrm{PVC}_{15}$ electrode since it did not undergo electrochemical oxidation. Once electrochemical oxidation occurs, as shown in Figure 3(b), the process clearly affects the electrode surface, creating many pores that allow pollutants to enter; thus leading to an electrochemical oxidation reaction occurring inside the electrode [26, 27] and resulting in a working electrode for landfill leachate treatment.

\section{Characterisation of landfill leachate after electrochemical treatment}

Selected values of water quality parameter (colour, $\mathrm{COD}, \mathrm{NH}_{3}-\mathrm{N}$, and total $\mathrm{P}$ ) on landfill leachate before and after electrolysis were analysed in optimum operating conditions, as previously mentioned. The results obtained show that the electrochemical oxidation process was able to reduce the colour, $\mathrm{COD}, \mathrm{NH}_{3}-\mathrm{N}$ and total $\mathrm{P}$ values in the landfill leachate. The removal percentages in colour, $\mathrm{COD}, \mathrm{NH}_{3}-\mathrm{N}$, and total $\mathrm{P}$ were not less than $80 \%, 91 \%, 73 \%$, and $84 \%$, respectively (Figure 4).

Reduction in COD value was due to the breaking down of large molecules into small molecules, which chemically and/or biologically eases the oxidisation process in the electrochemical oxidation technique [28, 29]. This breakdown process is supported by the existence of self-generated hypochlorite ions, which can reduce the concentration of organic compounds [30,31]. The measurement of $\mathrm{pH}$ of the landfill leachate showed that all samples were in alkaline conditions, changing to neutral upon completion of electrochemical oxidation duration due to the formation of a carbonate buffer from the $\mathrm{CO}_{2}$ produced at the end of the electrolysis process.

Colour is known as an important pollutant indicator in leachates. Therefore, besides testing the organic and nitrogen compound pollutants, colour removal was also investigated. Together with the electro-oxidation process, a strong oxidation process also occurred, to ensure the removal of colour-causing pollutants. This study achieved satisfactory findings for highly-coloured landfill leachates. This could be due to the increased generation of $\mathrm{OCl}^{-}$species that can oxidise coloured substances. During electrochemical oxidation, $\mathrm{OCl}^{-}$was produced due to the presence of chloride ions responsible for making hypochlorite ions, which then degrade the pollutants in leachate [32]. High 
$\mathrm{NH}_{3}-\mathrm{N}$ removal efficiencies can be achieved via the electro-oxidation process. Removal of nitrogen compounds can be explained by the mechanism used in this process.

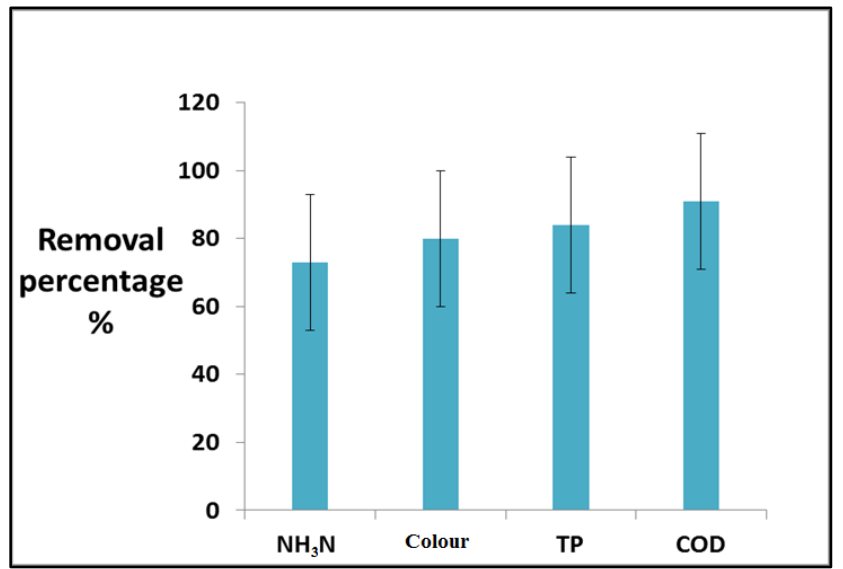

Figure 4. Removal efficiency of $\mathrm{C}^{\text {rubber tree }}{ }_{60} \mathrm{C}^{\mathrm{G}}{ }_{15} \mathrm{Co}_{10} \mathrm{PVC}_{15}$ anode in the electrochemical oxidation process with $10 \mathrm{~V}, 1.5 \%(\mathrm{w} / \mathrm{v}) \mathrm{NaCl}$, and $\mathrm{pH} 4$

\section{Conclusion}

Charcoal powders obtained from commercially available charcoal and charcoal prepared from palm oil, rubber, coconut, and mangrove trees were used to fabricate composite electrodes in this study. The results showed that the best electrode was fabricated from rubber tree charcoal according to the composition of $\mathrm{C}_{60} \mathrm{C}_{15}^{\mathrm{G}} \mathrm{Co}_{10}-\mathrm{PVC}_{15}$, yielding removal percentages in colour, $\mathrm{COD}, \mathrm{NH}_{3} \mathrm{~N}$, and total $\mathrm{P}$ of $80 \%, 91 \%, 73 \%$, and $84 \%$, respectively, under optimum operating conditions of sodium chloride $(\mathrm{NaCl})$ concentration of $1.5 \%(\mathrm{w} / \mathrm{v})$ as the supporting electrolyte, an applied voltage of $10 \mathrm{~V}$, an operating time of $120 \mathrm{~min}$, and a $\mathrm{pH}$ of 4 , using stainless steel as the cathode.

The variable pressure scanning electron microscope (VPSEM) analysis showed that rubber tree charcoal powder is the best type of charcoal for fabricating the composite electrode in this study due to its many holes and more surface area available for adsorption and reaction. The field emission scanning electron microscopy (FESEM) shows the presence of voids on the electrode surface before and after the electrolysis of the leachate sample, which improves the electrochemical oxidation of landfill leachates. Hence, the charcoal-based metallic composite electrode used in this study has proven efficient in the electrochemical treatment of landfill leachates.

\section{Acknowledgement}

The authors gratefully acknowledge the funding provided by Universiti Kebangsaan Malaysia and the Ministry of Higher Education, Malaysia, through grant number FRGS/2/2013/SG01/UKM/01/1.

\section{References}

1. Wu, J. J., Wu, C. C., Ma, H. W. and Chang, C. C. (2004). Treatment of landfill leachate by ozone-based advanced oxidation processes. Chemosphere, 54(7): 997-1003.

2. Kurniawan, T. A., Lo, W. H. and Chan, G. Y. (2006). Physico-chemical treatments for removal of recalcitrant contaminants from landfill leachate. Journal of hazardous materials, 129(1): 80-100.

3. Jumaah, M. A., Othman, M. R. and Yusop, M. R. (2016). Characterization of leachate from Jeram sanitary landfill-Malaysia. International Journal of ChemTech Research, 9(8): 571-574.

4. Xu, Z. Y., Zeng, G. M., Yang, Z. H., Xiao, Y., Cao, M., Sun, H. S., Ji, L. L. and Chen, Y. (2010). Biological treatment of landfill leachate with the integration of partial nitrification, anaerobic ammonium oxidation and heterotrophic denitrification. Bioresource Technology, 101(1): 79-86.

5. Cho, S. P., Hong, S. C. and Hong, S. I. (2002). Photocatalytic degradation of the landfill leachate containing refractory matters and nitrogen compounds. Applied Catalysis B: Environmental, 39(2): 125-133. 
Majd Ahmed Jumaah et al: OPTIMIZATION OF SELECTED CHARCOAL POWDER COMPOSITE ELECTRODE FOR ELECTROCHEMICAL TREATMENT OF LANDFILL LEACHATE

6. Lim, Y. N., Shaaban, M. G. and Yin, C. Y. (2009). Treatment of landfill leachate using palm shell-activated carbon column: Axial dispersion modeling and treatment profile. Chemical Engineering Journal, 146(1): 86-89.

7. Neczaj, E., Okoniewska, E. and Kacprzak, M. (2005). Treatment of landfill leachate by sequencing batch reactor. Desalination, 185(1): 357-362.

8. Galeano, L. A., Vicente, M. Á. and Gil, A. (2011). Treatment of municipal leachate of landfill by Fenton-like heterogeneous catalytic wet peroxide oxidation using an $\mathrm{Al} / \mathrm{Fe}$-pillared montmorillonite as active catalyst. Chemical Engineering Journal, 178(15): 146-153.

9. Li, W., Hua, T., Zhou, Q., Zhang, S. and Li, F. (2010). Treatment of stabilized landfill leachate by the combined process of coagulation/flocculation and powder activated carbon adsorption. Desalination, 264(1): 56-62.

10. Hasar, H., Unsal, S. A., Ipek, U., Karatas, S., Cinar, O., Yaman, C. and Kinac1, C. (2009). Stripping/flocculation/membrane bioreactor/reverse osmosis treatment of municipal landfill leachate. Journal of Hazardous Materials, 171(1): 309-317.

11. Tabet, K., Moulin, P., Vilomet, J. D., Amberto, A. and Charbit, F. (2002). Purification of landfill leachate with membrane processes: Preliminary studies for an industrial plant. Separation Science and Technology, 37(5): 1041-1063.

12. Bashir, M. J., Isa, M. H., Kutty, S. R. M., Awang, Z. B., Aziz, H. A., Mohajeri, S. and Farooqi, I. H. (2009). Landfill leachate treatment by electrochemical oxidation. Waste Management, 29(9): 2534-2541.

13. Jumaah, M. A. and Othman, M. R. (2015). Decolorization of landfill leachate using electrochemical oxidation technique. In AIP Conference Proceedings, 1678(1): 050032.

14. Jumaah, M. A. and Othman, M. R. (2015). Study the efficiency of various metal powder composition electrodes based on landfill leachate treatment. International Journal of ChemTech Research, 8(12): 559-563.

15. Martínez-Huitle, C. A. and Brillas, E. (2009). Decontamination of wastewaters containing synthetic organic dyes by electrochemical methods: A general review. Applied Catalysis B: Environmental, 87(3): 105-145.

16. Jumaah, M. A., Othman, M. R. and Yusop, M. R. (2016). Batch method treatment of landfill leachate using charcoal composite. International Journal of ChemTech Research, 9(8): 583-586.

17. American Public Health Association (2005). Standard methods for the examination of water and wastewater, $21^{\text {st }}$ edition; American Public Health Association: Washington, D.C.

18. Hamdan, M. S., Nordin, N. and Amir, S. F. M. (2011). Electrochemical behaviour of Ni and Ni-PVC electrodes for the electroxidation of ethanol. Sains Malaysiana, 40(12): 1421-1427.

19. Gubernat, M., Tomala, J., Frohs, W., Fraczek-Szczypta, A. and Blazewicz, S. (2016). De-agglomeration and homogenisation of nanoparticles in coal tar pitch-based carbon materials. Journal of Nanoparticle Research, 18(3): 56-69.

20. Shendkar, C. D., Torane, R. C., Mundhe, K. S., Lavate, S. M., Pawar, A. B. and Deshpande, N. R. (2013). Characterization and application of activated carbon prepared from waste weed. International Journal of Pharmacy and Pharmaceutical Sciences, 5(2): 527-529.

21. Jumaah, M. A., Othman, M. R. and Yusop, M. R. (2016). Electrochemical treatment of landfill leachate: Optimization of COD removal using charcoal-graphite-cobalt-polyvinyl chloride electrode. Research Journal of Pharmaceutical, Biological and Chemical Sciences, 7(5): 2812-2816.

22. Blanco, J., Torrades, F., De la Varga, M. and García-Montaño, J. (2012). Fenton and biological-Fenton coupled processes for textile wastewater treatment and reuse. Desalination, 286: 394-399.

23. Zakaria, Z., Nordin, N., Hasan, S. Z., Baharuddin, N. A., Jumaah, M. A. and Othman, M. R. (2015). Decolorization of reactive orange 16 dye using fabricated charcoal base metallic composite electrode. Malaysian Journal of Analytical Sciences, 19(3): 493-502.

24. Zhang, L. L. and Zhao, X. S. (2009). Carbon-based materials as supercapacitor electrodes. Chemical Society Reviews, 38(9): 2520-2531.

25. Ratnasingam, J., Ioras, F. and Wenming, L. (2011). Sustainability of the rubber wood sector in Malaysia. Notulae Botanicae Horti Agrobotanici Cluj-Napoca, 39(2): 305-311.

26. Sanroman, M. A., Pazos, M., Ricart, M. T. and Cameselle, C. (2004). Electrochemical decolourisation of structurally different dyes. Chemosphere, 57(3): 233-239.

27. Chang, X., Thind, S. S. and Chen, A. (2014). Electrocatalytic enhancement of salicylic acid oxidation at electrochemically reduced $\mathrm{TiO}_{2}$ nanotubes. ACS Catalysis, 4(8): 2616-2622. 
28. Jumaah, M. A. and Othman, M. R. (2015). Optimization of operating conditions for landfill leachate treatment using electrochemical oxidation technique. International Journal of ChemTech Research, 8(2): 783-787.

29. Chen, G. (2004). Electrochemical technologies in wastewater treatment. Separation and Purification Technology, 38(1): 11-41.

30. Jumaah, M. A. and Othman, M. R. (2015). COD removal from landfill leachate by electrochemical method using charcoal-PVC electrode. International Journal of ChemTech Research, 8(12): 604-609.

31. Jumaah, M. A., Othman, M. R. and Zakaria, Z. (2015). Fabrication of selected metal powder composite electrode for landfill leachate treatment using electrochemical method. International Journal of Chemical Sciences, 13(2): 943-954.

32. Jumaah, M. A., Othman, M. R., Yusop, M. R., Salimon, J., Khalaf, B. and Khalik, W. M. A. W. M. (2017). Charcoal base metallic composite electrode for wastewater treatment. Malaysian Journal of Analytical Sciences, 21(6): 1432-1437. 